\title{
Intra-Industry Trade in a Rapidly Globalizing Industry: The Case of Wine ${ }^{1}$
}

\author{
Kym Anderson \\ Wine Economics Research Centre \\ University of Adelaide \\ Douglas Nelson \\ Murphy Institute \\ Tulane University
}

Joseph Francois

World Trade Institute

University of Bern

Glyn Wittwer

Centre of Policy Studies

Victoria University

December 2015

\footnotetext{
${ }^{1}$ We dedicate this paper to David Greenaway: scholar of intra-industry trade, lover of wine.
} 


\section{Introduction}

Wine is one of the oldest products to be traded over long distances Lukacs (2012), (Pellechia, 2006, Simpson, 2011, Unwin, 1991). Indeed, there is evidence of Bronze Age trade not only in wine but also in the paraphernalia needed to store, process, and drink wine (Piggot 1959). In more recent times, as we detail below, the wine trade has grown dramatically in the post-War period on both the intensive and extensive margins. In this paper we explore some of the gross facts about the growth of the global wine industry, leaving theoretical development for later work. The next section provides a basic narrative account of recent developments in the world wine industry, the following section applies some basic network measures to characterize the structure and dynamic of the product's international trade, and this is followed by a more detailed analysis of intra-industry trade in wine.

\section{The world wine economy}

The past two decades have seen globalization of the world's wine markets proceed like never before, in both speed and comprehensiveness. There was a degree of trade expansion in the five decades to World War I, but that was mostly in response to the outbreak of Phylloxera that destroyed the majority of vines in Europe and saw French wineries invest in huge plantings in North Africa (Meloni and Swinnen, 2014). Until the late $20^{\text {th }}$ century, interactions across continents involved little more than the exporting of vine cuttings and of traditional production expertise. Indeed prior to 1990 most wine was consumed in the country of production (if one considers the Frenchowned vineyards in nearby French colonies of North Africa as part of France), ${ }^{2}$ and those countries were mostly on or near the Mediterranean Sea.

The fall in transport and communication costs since the 1980s is largely responsible for the recent globalization of the industry. On the demand side, as

\footnotetext{
${ }^{2}$ If Algeria etc. are treated as separate countries, then France switched from being a net exporter of wine up to 1880 to being a net importer for the next 100 years, with a considerable degree of intraindustry trade during that period (importing low-quality wine from North Africa and to a lesser extent southern European countries, and exporting mainly high-quality wines from Champagne, Bordeaux and Burgundy).
} 
incomes grew and access to television and the internet spread, so tastes broadened and an ever-greater variety of products has been sought by consumers, including for beverages.

On the supply side, the fall in travel and communication costs has made it more affordable for producers to consider exporting, and for some large wineries to also engage in cross-border mergers or acquisitions. Falling international trade costs plus de-regulation of liquor retailing from the 1980s also allowed large supermarket chains to become the major buyers not only of branded bottled or bag-in-box wines but also of bulk wine for building their own house brands.

Retailing through such chain stores requires large quantities of homogenous wine year after year. Producers in the New World were more adept at initially responding to that new demand, creating a huge new category of robust, fruity 'commercial premium' wines that fall between expensive fine wines and cheap nonpremium (or 'table') wines.

The share of global wine production exported, which had always been below 15 percent and mostly Mediterranean or intra-European, grew dramatically from the late 1980s. By 2012 it exceeded 40 per cent. The New World was the main contributor, with its share of global wine exports rising from 3 per cent in the late 1980s to 25 percent (if sparkling wine is excluded) by 2004 (Anderson, Norman and Wittwer 2003).

Recognizing their relatively poor performance, Europe's wine producers during the past decade have been adapting their practices to compete. The three leading European wine-exporting countries as a group now export almost half their production, up from just one-fifth a generation ago.

Simultaneously, New World producers are seeking to expand their exports of more-expensive wines to complement their lower-end products. The next phase of wine's globalization therefore may involve a convergence whereby both groups produce terroir-driven super-premium wines alongside more-affordable 'commercial premium' branded wines. Meanwhile, cheap basic non-premium wines are continuing their demise in both Europe and the New World.

Technological developments are rapidly altering the means of exporting commercial premium wines. In the past decade or so the share of wine that is exported from the New World in bulk shipping containers has risen from less than 15 to more than 40 percent (and to 57 percent for Australia by 2014). Bottling in the 
country of destination is sometimes cheaper, and it lowers the cost and carbon footprint of shipping. By shipping in 24,000-litre bladders to fit 20-foot containers, this new shipping technology offers greater opportunities for buyers to blend wines from any region of the world as relative prices alter - and to meet changing retail demands in the destination country more rapidly.

Greater openness to trade means winemakers and hence grape growers are far more exposed now than pre-1990 to exchange rate volatility, and also to greater import competition in their domestic market as consumers are better able to choose from an ever-broader range of wines (Anderson and Wittwer, 2013). The share of imports in domestic consumption in Australia, for example, rose from an average of 3 percent in 2000-04 to 15 percent by 2013 in volume terms, and around 20 percent in value terms (Anderson and Aryal, 2015). Wide fluctuations in exchange rates since the global financial crisis began in 2008 have substantially altered national rankings of New World wine-exporting countries (Figure 1).

--Figure 1 about here--

Increased openness and international travel have also altered tastes and preferences not only on both sides of the North Atlantic but also in Asia. Nowhere has this been more obvious in the case of wine than in China. Chinese wine imports grew more than 50 percent per year during 2006-12. With the number of middle class in China currently around 250 million and growing at around 10 million per year, and with grape wine accounting for less than 5 percent of alcohol consumption, further large increases in wine consumption are expected. How much of that Chinese demand will be supplied by domestic producers is difficult to guess. While import growth is likely to continue for the foreseeable future (Anderson and Wittwer, 2015), some exports also might begin to emerge from China in the future if there turns out to be a miss-match between the qualities of the wines produced and demanded domestically.

\section{Structure of the world wine web}

In this section, we extend our discussion of the previous section by applying tools of network analysis to data on global wine trade. We focus specifically on two interesting facts about the structure of the global wine economy: the overall growth in the breadth and depth of those markets, and the stability of the core of that economy. 
Table 1 shows the evolution of total trade from 1964 through 2009. It is clear that the global wine economy expanded dramatically over this period. Even though the number of wine-trading countries increased by 50 percent (much of this being new countries, formed in a variety of ways, but some being new importing or exporting countries), the number of links between countries increased by 450 percent and the volume of trade increased more than 45 fold! This suggests that not only are more countries involved in importing and/or exporting wine, but these countries are trading with more partners and that the links themselves involve more trade on average. Direct evidence of this is in the next several rows in Table $1 .^{3}$

--Table 1 about here--

In network analysis, degree is simply the number of links between a given node (i.e. economy in our case) and other nodes. Because we consider both exports and imports as links, each node is potentially linked to every other node via exports and imports, thus we show both "out degree" (economies to which a given economy is linked by exports) and "in degree" (economies to which a given economy is linked by imports). The country that exported to the largest number of countries in 1964 (France) exported to 141 countries. In fact, France was the country with the maximum out degree in every year in our data, and by 2009 it was exporting to 190 countries.

Because we are also interested in the value of exports or imports of wine between a pair of countries, we represent the structure of trade by considering the links between a pair of nodes as weighted by the value of exports or imports. France was also the country with the highest total value of exports (weighted out degree) in every year except 1964 (when Algeria was the country with the highest weighted out degree, though 97 percent of its exports went to France).

The mean number of links rises strongly over this 45 -year period, from 8 to 22, while the mean weighted degree increases by a factor of $49 .{ }^{4}$ As we shall see, this growth is primarily a function of increasingly intensive trade among the core

\footnotetext{
${ }^{3}$ All of the statistics presented in tables 1 and 2 were calculated in UCINET (Borgatti et al., 2013). This source is a handy overview of network empirics as well as basic applications using UCINET. The appendix De Benedictis and Tajoli (2011) is a compact presentation of most of the definitions relevant to this paper.

${ }^{4}$ The mean degree and mean weighted degree are equal for in and out since, in either case, this is just total links divided by number of countries or total world trade in wine divided by number of countries.
} 
members of the world wine economy, but it should be noted that the median country, which was not an exporter in 1964, was exporting to six countries in $2009 .^{5}$

Table 1 shows similar growth in both the size and extent of importing in the world wine economy. The largest importer in 1964 was sourcing its wine from 34 supplier countries, and by 2009 this had more than doubled to 86 supplier countries. Similarly, the volume imported by the largest importer had increased by a factor of 23. Unlike the case of exports, where France has dominated over essentially the entire period, the identity of the largest importer has changed over time. Over this period Great Britain, the US and Germany were the largest importers by value, with Great Britain often substantially the largest. ${ }^{6}$ Over the first half of the period of our data, Great Britain usually has the largest number of suppliers, while in the latter half of our sample period this is usually the US. As with exports, we again find substantial growth in both the number of suppliers to and the imports of the median economy.

The previous two paragraphs suggest that the world wine web should have been growing progressively denser. The standard network-theoretic definition/measure of density is simply the number of (unweighted) links observed in the data as a proportion of the number of possible links. With $n$ countries, the number of possible links in a directed network (i.e. a network in which import links and export links are both possible) is just $[n(n-1)]$. Thus, density is the number in the second row of table 1 divided by the number of possible links. ${ }^{7}$ So, from 1964 to 2009 , density doubles, even though the number of nodes (i.e. countries) increases by just 50 percent. That is, not only do countries have more trading partners on average, but also the world wine economy is more intensely interconnected. By way of comparison, the density of the entire world trade web, as reported by De Benedictis and Tajoli (2011), also doubles over this period, however, density of total trade for approximately comparable years ranges from 0.27 in 1970 to 0.40 in $2000 .^{8}$ That is,

\footnotetext{
${ }^{5}$ Note that the median country will vary from year to year. The point here is simply that the number of wine-exporting countries clearly increases, and increases significantly.

${ }^{6}$ An exception to this statement is that in the first two periods in our data (1964 and 1969), France is by far the largest importer. However in both of these years three quarters of its imports were from Algeria. As these imports shrank over time, France remained a sizable importer, but never one of the largest importers of wine.

${ }^{7}$ In 1964 , with 152 countries, the denominator is 22952 , so density in 1964 is $1147 / 22952$ or 0.05 , as in the table.

${ }^{8}$ De Benedictis and Tajoli (2011) report values at 10-year intervals, starting in 1960 and ending in 2000 .
} 
as one would expect when comparing the network for a single commodity to the network for all commodities, the latter is consistently something like 5 times as dense as the wine trade network over the whole period.

While the world wine web extends quite broadly across the countries of the world, it is also the case that there is a small core of countries that accounts for most of this trade. One approach to identifying a core looks for a single country that dominates trade. Freeman's (1979) centralization measures seek to characterize the extent to which a network is dominated by a single node (importer or exporter). That is, centralization is a measure of compactness in the sense that a star network is maximally centralized (in a star network, every node except the center has degree one, while the center has degree $n-1)$. The centralization indicator measures the extent to which the world wine web deviates from the star network. Thus, UCINET calculates the sum of the differences between the degree of the most central node and all other nodes, as a fraction of the maximum possible sum of differences in a network with $\mathrm{n}$ nodes. While the world wine web extends quite broadly across the countries of the world, it is also the case that there is a small core of countries that accounts for most of this trade. On the one hand, unsurprisingly given what we have just seen in table 2, the level of concentration is quite low, but we observe an interesting pattern of increasing concentration up to around 1979 and then a decline, which is especially pronounced for exports. This reflects the dominance, early in our data of traditional exporters (especially France), and then the rise of new exporters.

The low centralization reflects the existence of a number of sizable exporters and importers. Thus, we might be interested in the importance of a core set of countries. We can construct the core in a rough-and-ready way by considering the top dozen wine producers, exporters and importers in 2009. ${ }^{9}$ Table 2 shows data illustrating the evolution of this core from 1964. The first thing to notice is that trade within this core rises from about half of world trade to nearly 90 percent before falling

\footnotetext{
${ }^{9}$ The top 12 producers in 2009 were: Italy, France, Spain, the US, Argentina, Chile, China, Australia, South Africa, Germany and Portugal. The top 12 exporters were: France, Italy, Spain, Australia, Chile, Germany the USA, Portugal, South Africa, New Zealand, Argentina, and Great Britain. The top 12 importers were: Great Britain, the US, Germany, Canada, Belgium-Luxembourg, Netherlands, Japan, Switzerland, Sweden, Denmark, France, and Russia. The union of these three lists gives a 21-country core as of 2009: France, Italy, Spain, the USA, Argentina, Australia, South Africa, Germany, Chile, China, Portugal, Great Britain, Canada, Belgium-Luxembourg, Netherlands, Japan, Switzerland, Sweden, Denmark, Russia, and New Zealand. It should be noted that Russia does not enter our data until 1994, and that for consistency we work with Russia combined with other former Soviet republics.
} 
back to 80 percent. ${ }^{10}$ As with the world wine web as a whole, the density of trade in the core nearly doubles over the period covered by our data. However, trade in the core is 10 times as dense as in the global wine economy as a whole. Centralization of this core is on the order of 10 to 20 times greater than the world economy as a whole, but still shows the same pattern of rising, then declining centralization.

--Table 2 about here-

\section{Intra-Industry Trade in Wine}

In this section, we turn to analysis of the pattern of trade in wine based on the Grubel and Lloyd index of intra-industry trade. What we mean by intra-industry trade is the case where partners both import to and export from each other ( $a k a$ two-way trade) (Greenaway and Milner, 1986, Grubel and Lloyd, 1975). Two-way trade in wine can reflect consumer interest in final wine varieties that differ by country of origin, such as trade in different wine varieties for final consumption between France and Spain. However, a great deal of wine trade is actually trade in bulk wine that is then mixed with domestic wine, or with wine imported from other countries, before packaging for final consumers (COGEA.S.r.l., 2014). In this sense, two-way trade in wine reflects demand at both the final and intermediate product levels.

On a bilateral basis, we define the intra-industry trade index (in this case for wine) $I I T_{i, j}$ between countries $i$ and $j$ as a function of imports by country $j$ from $i M_{i, j}$ and imports by country $i$ from country $j M_{j, i}$ as follows:

$$
I I T_{i, j}=1-\left[\frac{\left[M_{i, j}-M_{j, i}\right\rceil}{M_{i, j}+M_{j, i}}\right]
$$

In equation (1), the last term in square brackets represents the share of bilateral trade that is classified as net trade, or as reflecting inter-industry trade. The remaining share is then the share of trade that is intra-industry or two-way, meaning it reflects trade that is balanced in both directions (where country $i$ imports from country $j$ and country $j$ imports from country $I$ to the same extent). Note there is symmetry with the definition in (1), where $I I T_{i, j}=I I T_{j, i}$.

\footnotetext{
${ }^{10}$ The 12 top exporters as of 2009 account for well over 90 percent of world trade in wine in every year in our sample, even though a number of these countries exported no wine, or very little wine, in the early years of our sample period. In fact, France, Italy, Spain, and Portugal account for around 90 percent of world trade in wine in 1964 and 1969. Germany plays an increasing role, especially from 1979, and from 1999 Australia becomes a major world exporter of wine.
} 
Starting from equation (1) we can also define an intra-industry trade index for country $j$ trade with the world as a whole (where we take all trading partners of $j$ collectively). In formal terms, we define this aggregate index $I I T_{j, \text { world }}$ as follows:

$$
\text { (2) } \quad I I T_{j, \text { world }}=1-\sum_{i}\left[\frac{\left[M_{i, j}-M_{j, i}\right]}{\sum_{k} M_{k, j}+M_{j, k}}\right]
$$

We will work with both bilateral and aggregate IIT indexes as defined in equations (1) and (2). These are all calculated on the basis of trade data (bilateral imports) from the UN COMTRADE database.

Table 3 below presents the values of index $I I T_{j, \text { world }}$ for the 21 countries that account collectively for between 90 and 95 percent of global trade in wine over the period 1969-2009. ${ }^{11}$ There are some significant changes over the 40 years in the table. For example, we see that for Argentina, Australia and South Africa there is a discernable drop in the IIT share of trade with the world. In the case of these countries, and as will become clearer when we turn to bilateral flows below, this reflects their rise over those four decades as net exporters to the rest of the world. In contrast, the IIT share of trade also fell dramatically for China, but in this case it is because of China's rise as a wine importer.

--Table 3 about here--

Globally, changes in net positions as exporters or importers are reflected in changes in the aggregate IIT indexes in Table 3 . To better understand these changes, in Figure 2 we provide bilateral IIT indexes as defined in equation (1). ${ }^{12}$ In comparing the pattern in 2009 with 1969, we see more pair-wise relationships defined by a high share of IIT trade in total pair-wise trade. This includes for example Belgium-Luxemburg with Switzerland, South Africa with Argentina, and South Africa with France.

-- Figure 2 about here--

However, while we see more pairs engaged in IIT trade defined in trade share terms, much of this IIT trade takes place in the context of relatively low levels of total

\footnotetext{
${ }^{11}$ Formally, we have taken the union of the set of the top 11 exporters and the top 15 importers for 2009. The combined share of these countries over time remains consistently between 90 and 95 percent on a value basis over the period 1969 to 2009. See note 8 .

${ }^{12}$ The full set of figures for intervening decades are available as part of the on-line annex.
} 
trade on a volume basis. For this reason, in Figure 3, we present the level of intraindustry trade for each of the dyads in the figures. In formal terms, we can define the level of intra-industry trade $L I I T_{i, j}$ as follows:

$$
\operatorname{LIIT}_{i, j}=\left(1-\left[\frac{\left\lceil M_{i, j}-M_{j, i}\right\rceil}{M_{i, j}+M_{j, i}}\right]\right)\left(M_{i, j}+M_{j, i}\right)
$$

In Figure 3, cells are scaled by the maximum value of $L I I T_{i, j}$ for the corresponding year relating to each Figure. On a level instead of a share basis, in 1969 the great bulk of two-way trade in wine was between France and Italy, with a smaller flow (approximately 25 percent of the France-Italy trade) between Germany and the Netherlands. What we see by 2009 is a spread of two-way trade. France and Italy still show the greatest level of intra-industry trade, reflecting bulk trade and well established blending patterns (COGEA 2014). However, we also now have relatively high volumes of intra-industry trade between France and Spain, Germany and the United States, and Italy and the United States.

--Figure 3 about here--

As a further step in decomposition, in Figure 4 we present net export positions by country pair. Again with reference to equation (1) we are now working with value of the term $M_{i, j}-M_{j, i}$ entering into the right hand side of equation (1). These figures provide a different perspective from the value of intra-industry trade in Figure 3. For example, while we have substantial growth in the value of two-way trade between France in the United States (Figure 3) there is also substantial growth in net exports from France to the US (Figure 4). In contrast, while we have had substantial growth in the level of intra-industry trade between France and Italy (Figure 3), there is little change in the pattern of net trade (Figure 4).

--Figure 4 about here--

Another change evident from Figure 4 is the emergence of New World suppliers of wine, especially Australia (exporting to the United States and Great Britain), but to a lesser extent South Africa (to Germany, Great Britain and Sweden) and Chile (the United States and Great Britain). This pattern of change is especially evident when we examine the pattern of British wine trade. Figure 5 presents the evolution of Great Britain's IIT trade, and net import patterns, from 1969 through to 2009. In 1969, 
most trade was imports from France and Spain (left panel). We see high two-way trade indexes for Argentina, Belgium-Luxemburg, the Netherlands, and Sweden (centre panel). However, on a value basis, we see in the right panel of Figure 5 that this is primarily trade with the Netherlands (reflecting the role of both Britain and the Netherlands as re-export points). We have a substantial change in this pattern by 2009.

--Figure 5 about here--

At the end of the period covered by Figure 5, Britain has a more diversified pattern of import suppliers, with Australia, Chile, Italy, and South Africa all taking on more important positions, although still secondary vis-à-vis France. While Italy has steadily picked up market share in Britain, Spain has dropped off over the same period (left panel). In addition, when we compare IIT indexes with IIT values, we see a shift away from the Netherlands. On an index basis, Canada now shows the greatest two-way trade (centre panel), though this is clearly at low actual values of intraindustry trade (right panel). On a value basis, the most important partner in terms of Britain's two-way trade is now France (right panel) even though on a relative or share basis this trade relationship remains one of net imports (left and centre panels). We also see a growing pattern of two-way trade in wine with Denmark, both in share and value terms (centre and right panels).

\section{What next?}

How might total and intra-industry trade in wine change over the current decade? Recent global wine modeling studies by Anderson and Wittwer $(2013,2015)$ show that the outcome is likely to depend very much on changes in real bilateral exchange rates and the propensity of China to import versus producing more of its own wine. Since those variables are notoriously difficult to predict, Anderson and Wittwer offer several scenarios. A summary of the bilateral trade consequences from their mostlikely scenario is provided in Table 4. It suggests the US\$ value (in 2009 dollars) of global wine trade will rise by 19 percent between 2011 and 2018. But more than half of that rise is accounted for by imports of China and other Asian countries with the 
United States the only other country shown in Table 4 whose imports rise by (slightly) more than the global average of 19 percent. US exports grow by only 12 percent though. By contrast, Australian and New Zealand wine exports are projected to grow by more than 50 percent over the same 8-year period (mostly destined for China), while their imports grow by only two-thirds the global average, thanks to their real exchange rates depreciating in the scenario modeled.

--Table 4 about here--

\section{Conclusions}

The takeaway message from this paper is that the global wine industry is growing rapidly around a rather stable core of countries that are both sizable exporters and sizable importers. Not only do national economies vary considerably in the magnitude of their participation, but firms vary in size from dominating multi-product multinationals to modest-sized firms specializing in niche products. Trade itself reflects both trade in intermediate inputs (bulk wine for blending) and trade at the final product level. In future work, we plan to examine patterns of size (country and firm) in the data as well as the dynamics of structural evolution over time. Network analytic tools are a natural choice in addressing these questions. By matching production, consumption and trade data over time (Anderson and Nelgen 2011), we will also be able to examine the causal relationships between these factors. 


\section{References}

Anderson K. and Aryal N. R. (2015), Growth and cycles in Australia's wine industry : a statistical compendium, 1843 to 2013, (University of Adelaide Press, Adelaide, SA).

Anderson K. and Wittwer G. (2013), 'Modeling Global Wine Markets to 2018: Exchange Rates, Taste Changes, and China's Import Growth', Journal of Wine Economics, 8, 02, 131-58.

Anderson K. and Wittwer G. (2015), 'Asia's evolving role in global wine markets', China Economic Review, 35, 1-14.

Borgatti S. P., Everett M. G. and Johnson J. C. (2013), Analyzing social networks, (Sage Publications, Thousand Oaks, CA).

COGEA.S.r.l. (2014), 'Study on the Competitiveness of European Wines: Final Report', doi: 10.2762/56910, (Luxembourg: European Commission, Luxembourg Publications Office of the European Union).

De Benedictis L. and Tajoli L. (2011), 'The World Trade Network', The World Economy, 34, 8, 1417-54.

Freeman L. C. (1979), 'Centrality in social networks conceptual clarification', Social Networks, 1, 3, 215-39.

Greenaway D. and Milner C. (1986), The economics of intra-industry trade, (Basil Blackwell, Oxford).

Grubel H. G. and Lloyd P. J. (1975), Intra-industry trade: the theory and measurement of international trade in differentiated products, (Wiley, New York,).

Lukacs P. (2012), Inventing wine: a new history of one of the world's most ancient pleasures, (W.W. Norton \& Co., New York).

Meloni G. and Swinnen J. (2014), 'The Rise and Fall of the World's Largest Wine Exporter-And Its Institutional Legacy', Journal of Wine Economics, 9, 01, 333.

Pellechia T. (2006), Wine: the 8,000-year-old story of the wine trade, (Thunder's Mouth Press, New York).

Simpson J. (2011), Creating wine: the emergence of a world industry, 1840-1914, (Princeton University Press, Princeton).

Unwin T. (1991), Wine and the vine: an historical geography of viticulture and the wine trade, (Routledge, London; New York). 
Table 1: Network Statistics on World Wine Web, all countries, 1964 to 2009

$\begin{array}{lrrrrrrrrrr} & 1964 & 1969 & 1974 & 1979 & 1984 & 1989 & 1994 & 1999 & 2004 & 2009 \\ n \text { of countries } & 152 & 157 & 196 & 193 & 191 & 195 & 216 & 213 & 225 & 230 \\ n \text { of links } & 1147 & 1423 & 2029 & 2131 & 2015 & 2283 & 2997 & 3615 & 4660 & 5156 \\ \text { Total trade } & 587858 & 704647 & 1829924 & 4118851 & 3873040 & 6888756 & 8853214 & 14299819 & 21076262 & 26721601 \\ \text { Max out degree } & 141 & 148 & 169 & 173 & 168 & 165 & 183 & 181 & 195 & 190 \\ \text { Max weighted out } & 166155 & 234936 & 635669 & 1654576 & 1716800 & 3631749 & 4054235 & 6079691 & 6915577 & 8199769 \\ \text { Median out degree } & 0 & 0 & 1 & 1 & 1 & 1 & 1 & 2 & 4 & 6 \\ \text { Median weighted out } & 0 & 0 & 1 & 1 & 1 & 5 & 10 & 19 & 28 & 88 \\ \text { Out centralization } & 0.7 & 1.8 & 2.9 & 2.9 & 2.1 & 2.5 & 2.3 & 2.3 & 2.2 & 2.1 \\ \text { Mean degree } & 8 & 9 & 10 & 11 & 11 & 12 & 14 & 17 & 21 & 22 \\ \text { Mean weighted deg. } & 3867 & 4488 & 9336 & 21341 & 20278 & 35327 & 40987 & 67135 & 93672 & 116181 \\ \text { Max in degree } & 34 & 36 & 56 & 51 & 58 & 65 & 60 & 75 & 80 & 86 \\ \text { Max weighted in } & 219070 & 105796 & 293596 & 692263 & 1064519 & 1352308 & 1718869 & 2979401 & 5275938 & 5040290 \\ \text { Median in degree } & 6 & 7 & 8 & 9 & 8 & 9 & 11 & 13 & 15 & 18 \\ \text { Median weighted in } & 116 & 211 & 282 & 596 & 454 & 951 & 1225 & 1796 & 2201 & 3689 \\ \text { In centralization } & 0.9 & 0.8 & 1.3 & 1.2 & 1.3 & 0.9 & 1.0 & 1.1 & 1.6 & 1.4 \\ \text { Density } & 0.050 & 0.058 & 0.053 & 0.058 & 0.056 & 0.060 & 0.065 & 0.080 & 0.092 & 0.098\end{array}$

Source: Authors' calculations, based on UN COMTRADE data 
Table 2: Network Statistics on Core of World Wine Web (top 21 wine-trading countries), 1964 to 2009

$\begin{array}{lrrrrrrrrrr} & 1964 & 1969 & 1974 & 1979 & 1984 & 1989 & 1994 & 1999 & 2004 & 2009 \\ n \text { of countries } & 20 & 20 & 20 & 20 & 20 & 20 & 21 & 21 & 21 & 21 \\ n \text { of links } & 204 & 230 & 273 & 282 & 285 & 317 & 370 & 368 & 391 & 391 \\ \text { Total trade } & 29058 & 427870 & 1380868 & 3394735 & 3352158 & 6035842 & 7549519 & 12292198 & 17487763 & 21154106 \\ \text { Global proportion } & 0.49 & 0.61 & 0.75 & 0.82 & 0.87 & 0.88 & 0.85 & 0.86 & 0.83 & 0.79 \\ \text { Mean degree } & 10.2 & 11.5 & 13.7 & 14.1 & 14.3 & 15.9 & 17.6 & 17.5 & 18.6 & 18.6 \\ \text { Mean weighted } & & & & & & & & & & \\ \text { degree } & 14527 & 21394 & 69043 & 169737 & 167608 & 301792 & 359501 & 585343 & 832751 & 1007338 \\ \text { Normalized degree } & 2.0 & 2.4 & 3.2 & 3.0 & 2.1 & 2.1 & 2.2 & 2.4 & 3.0 & 3.3 \\ \text { Density } & 0.5 & 0.6 & 0.7 & 0.7 & 0.8 & 0.8 & 0.9 & 0.9 & 0.9 & 0.9 \\ \text { Out centralization } & 19.2 & 22.3 & 24.6 & 24.9 & 18.5 & 23.0 & 21.6 & 21.5 & 20.0 & 20.9 \\ \text { In centralization } & 9.2 & 8.6 & 9.9 & 9.5 & 11.3 & 7.6 & 8.1 & 9.7 & 15.7 & 12.9\end{array}$

Source: Authors' calculations, based on UN COMTRADE data 
Table 3: IIT indexes, top 21 wine-trading countries with the world, 1969 to 2009

\begin{tabular}{|c|c|c|c|c|c|}
\hline & 1969 & 1979 & 1989 & 1999 & 2009 \\
\hline Argentina (ARG) & 0.354 & 0.428 & 0.056 & 0.288 & 0.029 \\
\hline Australia (AUS) & 0.821 & 0.319 & 0.687 & 0.145 & 0.129 \\
\hline Belgium-Luxemburg (BLX) & 0.180 & 0.069 & 0.132 & 0.127 & 0.137 \\
\hline Canada (CAN) & 0.011 & 0.007 & 0.005 & 0.014 & 0.018 \\
\hline Switzerland (CHE) & 0.033 & 0.081 & 0.030 & 0.084 & 0.054 \\
\hline Chile (CHL) & 0.049 & 0.070 & 0.018 & 0.020 & 0.004 \\
\hline China (CHN) & 0.978 & 0.597 & 0.256 & 0.192 & 0.023 \\
\hline Germany (DEU) & 0.411 & 0.680 & 0.553 & 0.339 & 0.443 \\
\hline Denmark (DNK) & 0.038 & 0.004 & 0.033 & 0.016 & 0.168 \\
\hline Spain (ESP) & 0.024 & 0.011 & 0.094 & 0.164 & 0.171 \\
\hline France (FRA) & 0.122 & 0.388 & 0.162 & 0.149 & 0.149 \\
\hline United Kingdom (GBR) & 0.030 & 0.056 & 0.016 & 0.055 & 0.112 \\
\hline Hong Kong (HKG) & 0.010 & 0.003 & 0.035 & 0.027 & 0.003 \\
\hline Italy (ITA) & 0.328 & 0.156 & 0.250 & 0.160 & 0.142 \\
\hline Japan (JPN) & 0.676 & 0.008 & 0.003 & 0.004 & 0.010 \\
\hline Netherlands (NLD) & 0.419 & 0.078 & 0.061 & 0.121 & 0.117 \\
\hline Portugal (PRT) & 0.005 & 0.088 & 0.337 & 0.465 & 0.298 \\
\hline Former Soviet Union (SVU) ${ }^{a}$ & 0.406 & 0.456 & 0.200 & 0.465 & 0.033 \\
\hline Sweden (SWE) & 0.004 & 0.006 & 0.008 & 0.012 & 0.038 \\
\hline United States (USA) & 0.017 & 0.030 & 0.161 & 0.376 & 0.367 \\
\hline South Africa (ZAF) & 0.320 & 0.542 & 0.562 & 0.109 & 0.039 \\
\hline
\end{tabular}

${ }^{\mathrm{a}}$ For the former Soviet Union (SVU) we focus on trade between the Soviet Union, or countries that were part of the Soviet Union pre-1991, and the rest of the world.

Source: Authors' calculations, based on UN COMTRADE data 
Figure 1: Value of wine exports, New World countries, 1995 to 2014 (US\$ ‘000)

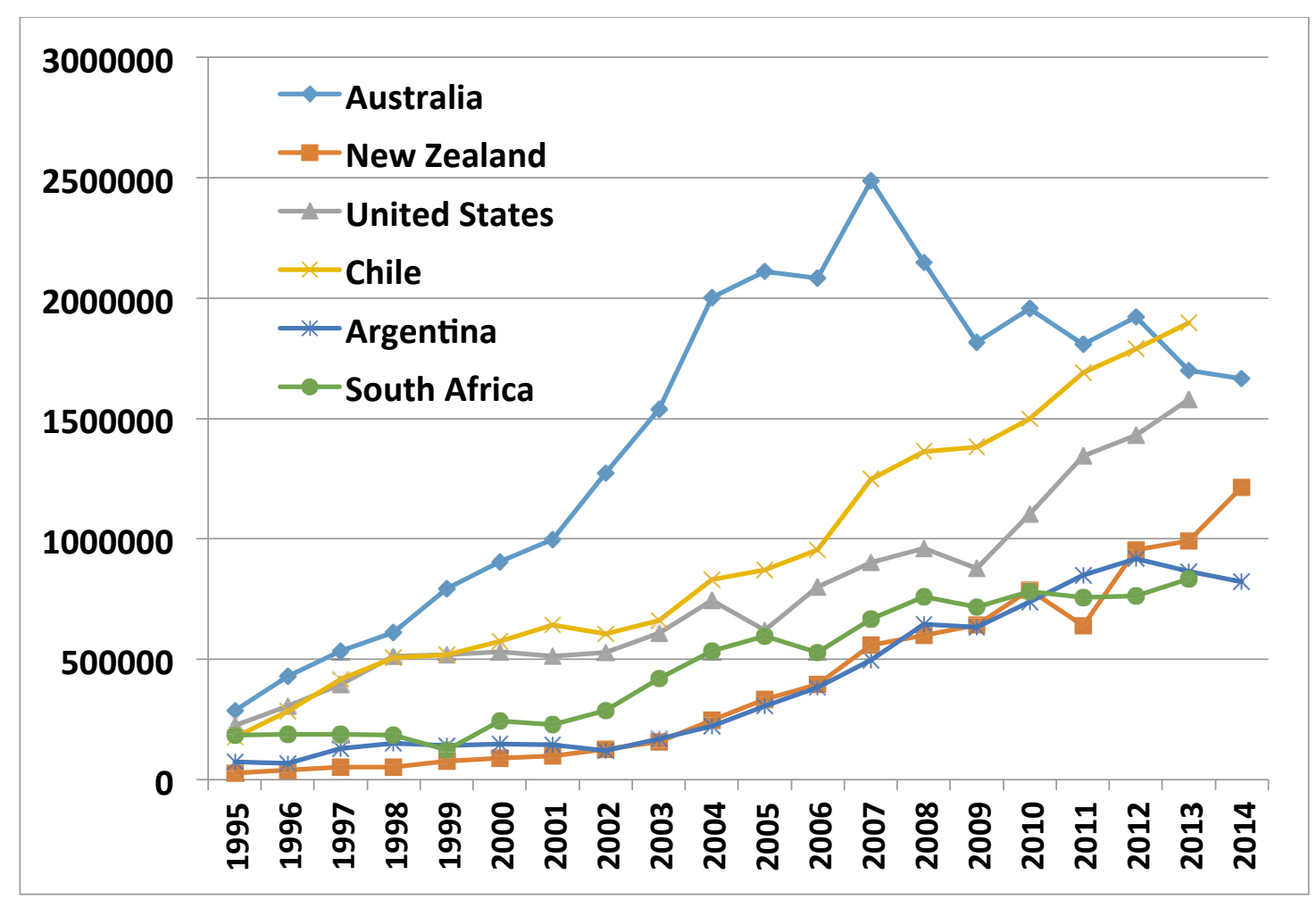

Source: Anderson (2015). 
Figure 2: IIT indexes, top trading countries, ${ }^{\mathrm{a}} 1969$ and 2009

(a) 1969

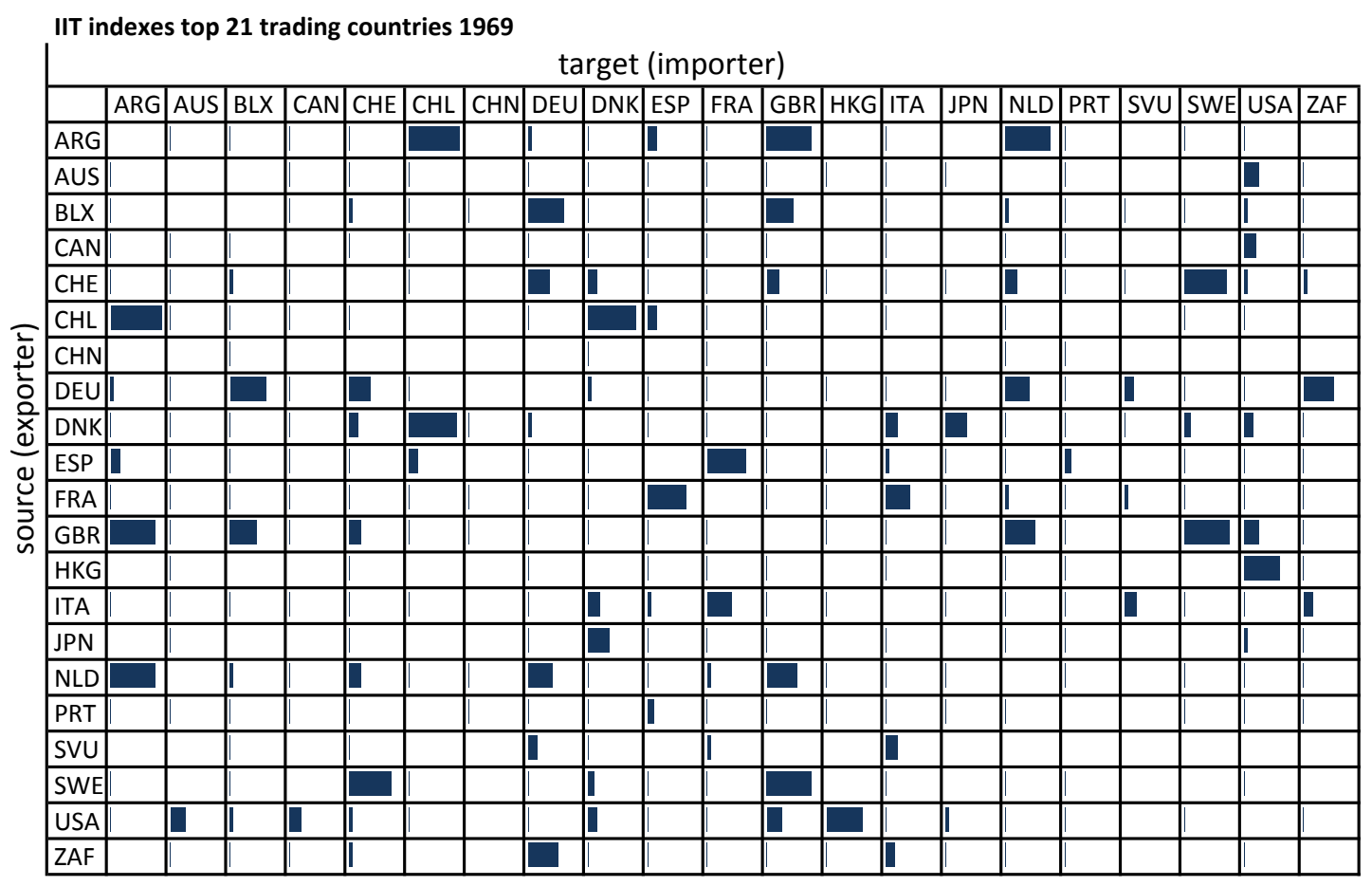

(b) 2009

target (importer)

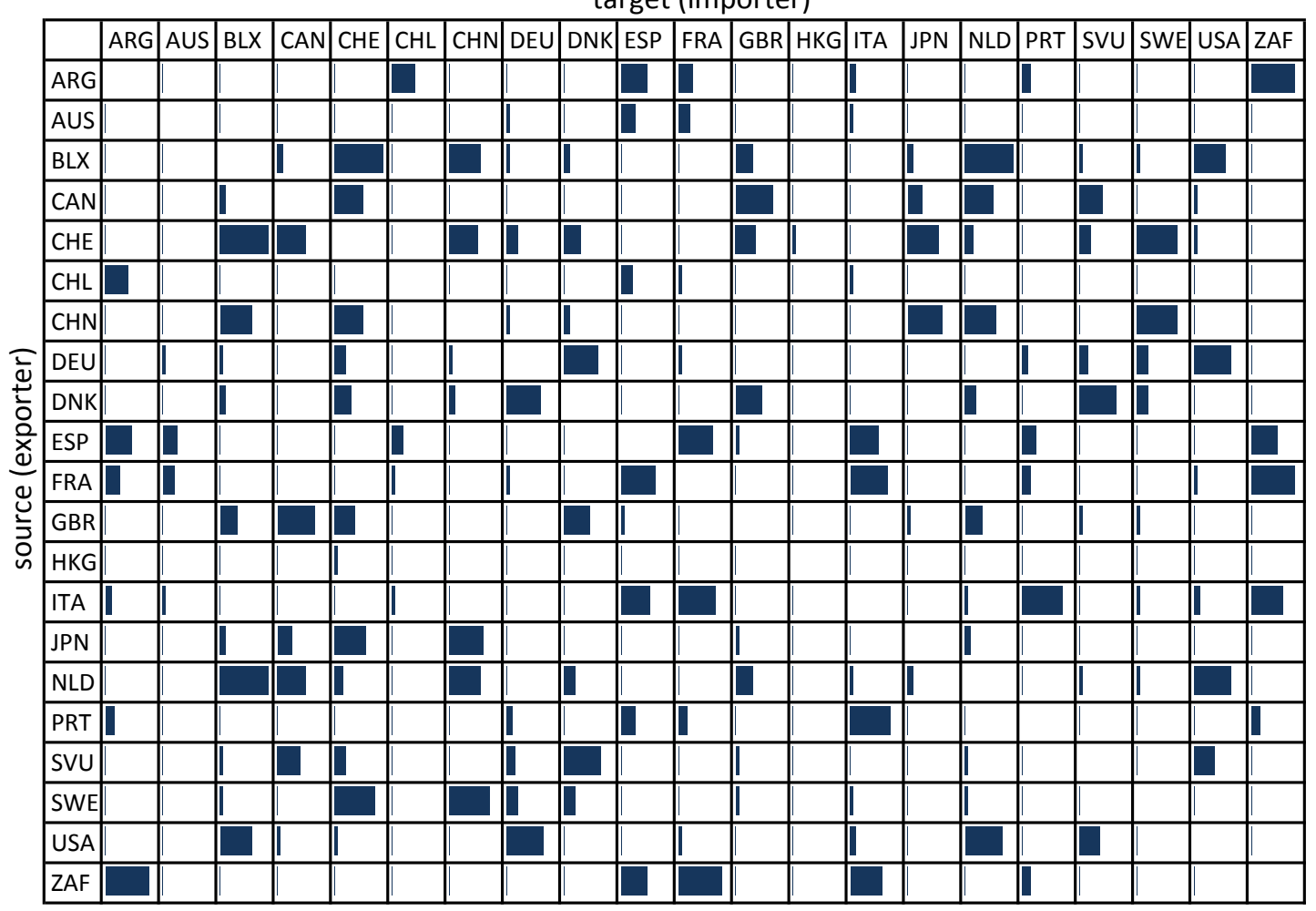

${ }^{\mathrm{a}}$ Cells are scaled by maximum value for IIT index.

Source: Authors' calculations based, on UN COMTRADE data 
Figure 3: Level of IIT (values), top 21 wine-trading countries, ${ }^{\text {a }} 1969$ and 2009

(a) 1969

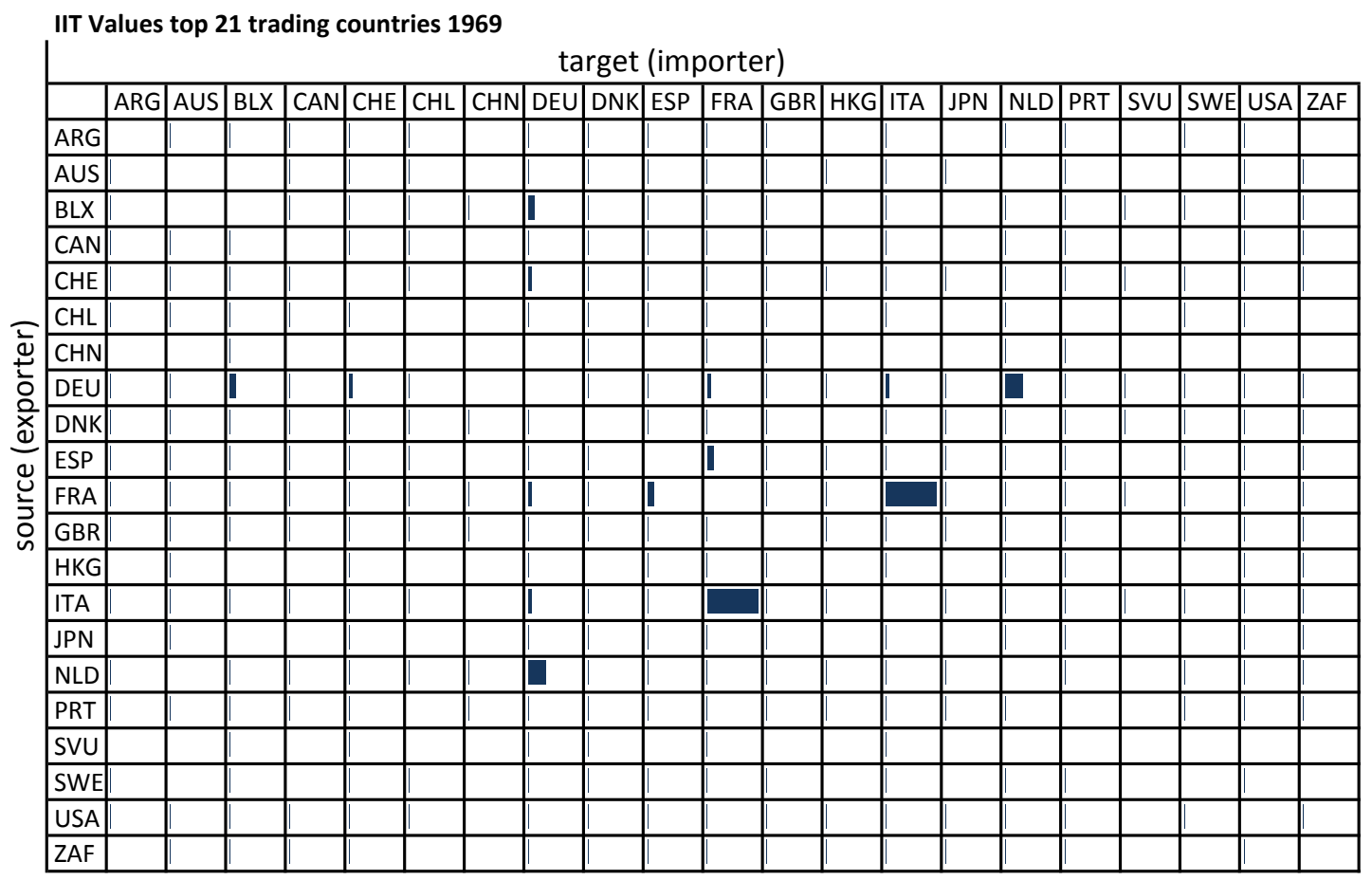

(b) 2009

target (importer)

\begin{tabular}{|c|c|c|c|c|c|c|c|c|c|c|c|c|c|c|c|c|c|c|c|c|c|}
\hline & \begin{tabular}{|l|l|} 
ARG \\
\end{tabular} & AUS & $B L X$ & CAN & $\mathrm{CHE}$ & $\mathrm{CHL}$ & $\mathrm{CHN}$ & \begin{tabular}{|l|l|}
$D E U$ \\
\end{tabular} & DNK & ESP & FRA & GBR & HKG & \begin{tabular}{|l|} 
ITA \\
\end{tabular} & |JPN & NLD & |PRT & svu & SWE & USA & \begin{tabular}{|l} 
ZAF \\
\end{tabular} \\
\hline \begin{tabular}{|l|} 
ARG \\
\end{tabular} & & & & & & & & & & & & & & & & & & & & & \\
\hline AUS & & & & & & & & & & & 【 & & & & & & & & & & \\
\hline BLIX & & & & & & & & & & & | & & & & & D & & & & & \\
\hline CAN & & & & & & & & & & & & & & & & & & & & & \\
\hline CHE & & & & & & & & & & & & & & & & & & & & & \\
\hline $\mathrm{CHL}$ & & & & & & & & & & & & & & & & & & & & & \\
\hline CHN & & & & & & & & & & & & & & & & & & & & & \\
\hline DEU & & & & & & & & & ॥ & $\|$ & | & & & & & & & $\|$ & & $\square$ & \\
\hline DNK & & & & & & & & & & & & & & & & & & & & & \\
\hline ESP & & & & & & & & & & & $\square$ & & & | & & & II & & & & \\
\hline FRA & & | & $\|$ & & & & & | & & $\square$ & & | & & \begin{tabular}{|l|} 
\\
\end{tabular} & & & | & & & 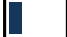 & | \\
\hline GBR & & & $\|$ & & & & & & & ॥ & $\pi$ & & & . & & & & & & $\|$ & \\
\hline $\mathrm{HKG}$ & & & & & & & & & & & & & & & & & & & & & \\
\hline ITA & & & & & & & & & & 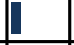 & $=$ & & & & & & $\|$ & & & $\square$ & \\
\hline \begin{tabular}{|l|l} 
JPN \\
\end{tabular} & & & & & & & & & & & & & & & & & & & & & \\
\hline NLD & & & 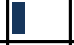 & & & & & & & & & & & & & & & & & $\|$ & \\
\hline \begin{tabular}{|l} 
PRT \\
\end{tabular} & & & & & & & & & & 1 & I & & & & & & & & & & \\
\hline SVU & & & & & & & & & & & & & & & & & & & & & \\
\hline SWE & & & & & & & & & & & & & & & & & & & & & \\
\hline USA & & & & & & & & \begin{tabular}{|l|} 
\\
\end{tabular} & & & 0 & & & $\square$ & & & & & & & \\
\hline ZAF & & & & & & & & & & & | & & & & & & & & & & \\
\hline
\end{tabular}

${ }^{a}$ Cells are scaled by maximum value for inter-industry trade flow in the table.

Source: Authors' calculations based, on UN COMTRADE data 
Figure 4: Net export positions by dyad, top 21 wine-trading countries, 1969 and 2009

(a) 1969

target (importer)

\begin{tabular}{|c|c|c|c|c|c|c|c|c|c|c|c|c|c|c|c|c|c|c|c|c|c|}
\hline & ARG & AUS & $\mathrm{BLX}$ & CAN & $\mathrm{CHE}$ & $\mathrm{CHL}$ & $\mathrm{CHN}$ & DEU & DNK & \begin{tabular}{|l|} 
ESP \\
\end{tabular} & \begin{tabular}{|l|} 
FRA \\
\end{tabular} & GBR & HKG & ITA & JPN & NLD & PRT & SVU & SWE & USA & ZAF \\
\hline \begin{tabular}{|l|} 
ARG \\
\end{tabular} & & 1 & 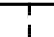 & $\mathrm{I}$ & i & $T$ & & $T$ & i & $T$ & i & $T$ & & 1 & & 1 & $i$ & & i & $T$ & \\
\hline AUS & 1 & & & 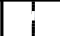 & 1 & 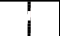 & & 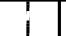 & $I$ & I & $I$ & T & $I$ & 1 & $I$ & & $I$ & & & 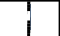 & 1 \\
\hline \begin{tabular}{|l|}
$B L X$ \\
\end{tabular} & 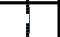 & & & I & + & 1 & $T$ & 1 & + & 1 & 4 & 1 & & 1 & & 1 & + & $\mathrm{I}$ & $T$ & 1 & 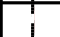 \\
\hline CAN & 1 & 1 & 1 & & 1 & 1 & & 1 & $I$ & 1 & 1 & 1 & & 1 & & 1 & I & & & 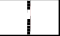 & 1 \\
\hline $\mathrm{CHE}$ & 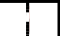 & 1 & 1 & $T$ & & $\mathrm{I}$ & & 1 & + & 1 & पㄴ & 1 & $T$ & 1 & $T$ & 1 & 1 & 1 & $T$ & 1 & 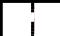 \\
\hline \begin{tabular}{|l|}
$\mathrm{CHL}$ \\
\end{tabular} & 1 & 1 & 1 & $I$ & 1 & & & $I$ & 1 & 1 & 1 & 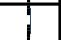 & & 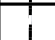 & & + & + & & 1 & + & \\
\hline $\mathrm{CHN}$ & & & $\perp$ & & & & & & 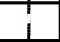 & & 1 & $I$ & $I$ & & & $I$ & 1 & & & . & \\
\hline DEU & 1 & 1 & 1 & 1 & $I$ & 1 & & & $I$ & 1 & $\square$ & 1 & $I$ & $\overline{4}$ & $I$ & 1 & 1 & 1 & $I$ & 1 & 1 \\
\hline DNK & 1 & 1 & 1 & 1 & 1 & $I$ & 1 & 1 & & $I$ & 1 & $I$ & & 1 & 1 & 1 & 1 & $I$ & 1 & $I$ & 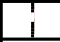 \\
\hline ESP & 1 & 1 & 1 & 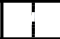 & 1 & 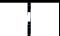 & & 1 & 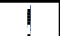 & & 1 & 尚 & 1 & 1 & 1 & 1 & $I$ & & $T$ & 1 & 1 \\
\hline \begin{tabular}{|l|l|} 
FRA \\
\end{tabular} & 1 & $I$ & 五 & 1 & $\sqrt{1}$ & $I$ & 1 & $\square$ & 1 & 1 & & D & $i$ & 1 & 1 & 1 & 4 & $I$ & 1 & $\square$ & 1 \\
\hline \begin{tabular}{|l|} 
GBR \\
\end{tabular} & $I$ & 1 & 1 & 1 & $I$ & 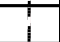 & I & 1 & $I$ & 다 & 0 & & 1 & 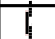 & 1 & $T$ & I & $i$ & 1 & 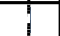 & 1 \\
\hline \begin{tabular}{|l|}
$\mathrm{HKG}$ \\
\end{tabular} & & 1 & & & + & & + & 1 & & 1 & + & $\mathrm{I}$ & & 1 & 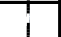 & 1 & + & & & 1 & 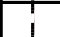 \\
\hline ITA & $I$ & 1 & $I$ & 1 & 1 & 1 & & 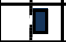 & $I$ & 1 & 1 & 1 & $I$ & & $I$ & 1 & I & I & $I$ & $\sqrt{7}$ & 1 \\
\hline JPN & & 1 & & & T & & & 1 & 1 & $I$ & 1 & 1 & 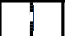 & 1 & & $I$ & 1 & & & $I$ & 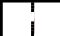 \\
\hline \begin{tabular}{|l|} 
NLD \\
\end{tabular} & $T$ & & 1 & $T$ & 1 & $T$ & $T$ & j & 1 & 1 & I & 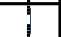 & 1 & 1 & $T$ & & 1 & & $T$ & $T$ & 1 \\
\hline PRT & 1 & $I$ & 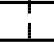 & $I$ & 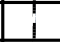 & & 1 & 1 & 1 & 1 & 1 & 1 & 1 & 1 & 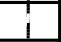 & $I$ & & & 1 & 1 & 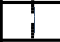 \\
\hline SVU & & & 1 & & 1 & & & 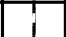 & 1 & & 1 & 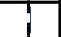 & & 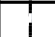 & & & & & & & \\
\hline SWE & 1 & & 1 & & 1 & $I$ & & $I$ & 1 & 1 & 1 & $I$ & & 1 & & $I$ & $T$ & & & $I$ & \\
\hline USA & 1 & 1 & 1 & 1 & 1 & 1 & & 4 & $I$ & 4 & $\square$ & 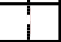 & $I$ & 证 & $I$ & 1 & 1 & & $I$ & & $I$ \\
\hline $\mathrm{ZAF}$ & & 1 & & I & 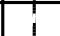 & & & 1 & 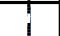 & 1 & 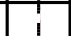 & 1 & 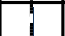 & 1 & + & 1 & + & & & 1 & \\
\hline
\end{tabular}

(b) 2009

target (importer)

\begin{tabular}{|c|c|c|c|c|c|c|c|c|c|c|c|c|c|c|c|c|c|c|c|c|c|}
\hline & ARG & AUS & $B L X$ & CAN & $\mathrm{CHE}$ & $\mathrm{CHL}$ & $\mathrm{CHN}$ & DEU & DNK & ESP & FRA & GBR & HKG & ITA & JPN & NLD & PRT & SVU & SWE & USA & ZAF \\
\hline ARG & & 1 & $I$ & 1 & 1 & 1 & $I$ & 1 & $I$ & I & $I$ & I & $I$ & I & $I$ & 1 & $I$ & I & $I$ & 1 & $I$ \\
\hline AUS & 1 & & i & 1 & 1 & 1 & $i$ & 1 & 1 & 1 & I & 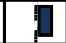 & I & 1 & 1 & $T$ & 1 & $T$ & 1 & $\overline{1}$ & 1 \\
\hline $\mathrm{BLX}$ & 1 & $I$ & & $I$ & 1 & I & 1 & $I$ & 1 & 1 & $\overline{5}$ & I & 1 & 1 & $T$ & $I$ & 1 & $I$ & 1 & I & 1 \\
\hline CAN & 1 & 1 & 1 & & 1 & I & 1 & 1 & 1 & I & 7 & i & 1 & 1 & 1 & I & 1 & 1 & 1 & 1 & 1 \\
\hline $\mathrm{CHE}$ & $I$ & 1 & $I$ & 1 & & 1 & $I$ & I & 1 & 1 & 1 & 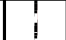 & 1 & I & I & 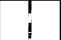 & 1 & 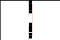 & I & i & 1 \\
\hline $\mathrm{CHL}$ & I & $T$ & I & 1 & i & & I & $T$ & I & 1 & 1 & 1 & I & $T$ & 1 & 1 & I & $T$ & I & $T$ & I \\
\hline $\mathrm{CHN}$ & 1 & 1 & 1 & 1 & 1 & 1 & & 1 & 1 & 1 & 1 & 1 & 1 & 1 & 1 & 1 & 1 & 1 & 1 & $I$ & 1 \\
\hline DEU & 1 & i & 1 & 1 & 1 & I & 1 & & 1 & 1 & 4 & 1 & 1 & $\square$ & 1 & 1 & 1 & I & 1 & i & 1 \\
\hline DNK & $I$ & 1 & $I$ & 1 & $I$ & 1 & $I$ & 1 & & 1 & 1 & 1 & I & 1 & $I$ & I & $I$ & 1 & I & 1 & $I$ \\
\hline ESP & I & 1 & 1 & 1 & 1 & 1 & I & 1 & $i$ & & I & 1 & I & 1 & I & 1 & I & 1 & I & 1 & 1 \\
\hline FRA & 1 & 1 & 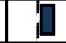 & 1 & 1 & I & $\pi$ & D & 1 & $I$ & & $\square$ & 1 & 1 & $\pi$ & 1 & T & 1 & $\pi$ & $\square$ & 1 \\
\hline GBR & 1 & $\square$ & 1 & $\mathrm{i}$ & $I$ & 1 & 1 & 1 & 1 & 1 & $\square$ & & 1 & d & $T$ & i & 1 & 1 & 1 & 1 & I \\
\hline HKG & $\mathrm{I}$ & $T$ & I & 1 & $\mathrm{I}$ & 1 & I & $T$ & $\mathrm{I}$ & 1 & 1 & 1 & & 1 & $I$ & 1 & 1 & $T$ & I & 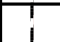 & 1 \\
\hline ITA & 1 & $T$ & 1 & $T$ & 1 & 1 & 1 & $\square$ & 1 & 1 & 1 & 11 & I & & 1 & 1 & 1 & 1 & $i$ & $\square$ & 1 \\
\hline JPN & 1 & 1 & 1 & 1 & 1 & 1 & 1 & 1 & 1 & 1 & 4 & $I$ & 1 & 1 & & 1 & 1 & $I$ & 1 & $I$ & 1 \\
\hline NLD & 1 & 1 & 1 & $\mathrm{i}$ & 1 & 1 & 1 & 1 & 1 & 1 & 4 & 1 & 1 & I & 1 & & 1 & 1 & 1 & I & 1 \\
\hline PRT & $I$ & $\begin{array}{l}1 \\
1\end{array}$ & I & 1 & $I$ & $\begin{array}{l}1 \\
1\end{array}$ & I & 1 & 1 & $\begin{array}{l}1 \\
1\end{array}$ & 1 & I & $I$ & $\begin{array}{l}1 \\
1\end{array}$ & $I$ & $\begin{array}{l}1 \\
1\end{array}$ & & 1 & I & $\begin{array}{l}T \\
\end{array}$ & 1 \\
\hline SVU & 1 & 1 & I & 1 & 1 & 1 & 1 & $T$ & 1 & 1 & I & $T$ & I & 1 & 1 & $T$ & i & & 1 & $T$ & I \\
\hline SWE & T & 1 & 1 & $I$ & 1 & $I$ & 1 & $I$ & 1 & $I$ & 1 & $I$ & 1 & 1 & 1 & $I$ & I & $I$ & & I & $T$ \\
\hline USA & 1 & ए & 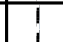 & 1 & 1 & 1 & $T$ & 1 & 1 & f & Q & 1 & $T$ & $\square$ & 1 & 1 & $T$ & 1 & 1 & & 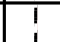 \\
\hline $\mathrm{ZAF}$ & $I$ & I & $I$ & i & I & 1 & I & 1 & 1 & 1 & 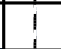 & 7 & I & 1 & $I$ & I & $I$ & 1 & 1 & T & \\
\hline
\end{tabular}

${ }^{\text {a }}$ Cells are scaled by maximum value for net exports.

Source: Authors' calculations based, on UN COMTRADE data 
Table 4: Projected changes in values of wine trade, 2011 to 2018 (US\$ million)

\begin{tabular}{|c|c|c|c|c|c|c|c|c|c|c|c|c|c|c|c|c|c|}
\hline & FRA & BLX & DEU & GBR & OWEM $^{\mathrm{a}}$ & RUS & $\mathrm{OECA}^{\mathrm{a}}$ & USA & CAN & $\mathrm{CHN}$ & JPN & OASIA $^{\mathrm{a}}$ & AUS & NZL & RofWM $^{\mathrm{a}}$ & World & \%change \\
\hline FRA & 0 & 202 & 35 & 121 & 363 & 32 & 24 & 337 & 119 & 683 & 176 & 382 & 3 & 3 & 151 & 2630 & 28 \\
\hline ITA & 11 & 7 & -52 & 0 & 95 & 23 & 12 & 161 & 51 & 148 & 19 & 26 & 2 & 1 & 24 & 528 & 9 \\
\hline PRT & 41 & 16 & -1 & 2 & 24 & 0 & 1 & 16 & 14 & 22 & 2 & 7 & 0 & 0 & 61 & 205 & 22 \\
\hline ESP & -17 & -3 & -47 & -15 & -23 & 0 & 2 & 28 & 4 & 94 & 3 & 7 & 0 & 0 & 13 & 46 & 2 \\
\hline DEU & 0 & 0 & 0 & -6 & -4 & 1 & 3 & 13 & 1 & 63 & 1 & 5 & 0 & 0 & 3 & 80 & 7 \\
\hline USA & -2 & -2 & -10 & -27 & -11 & -2 & -1 & 0 & -9 & 191 & -4 & 16 & 0 & 0 & -14 & 125 & 12 \\
\hline AUS & 1 & 3 & 0 & 42 & 24 & 0 & 1 & 115 & 33 & 649 & 3 & 50 & 0 & 9 & 3 & 933 & 52 \\
\hline ARG & 0 & 0 & -1 & -1 & -6 & -4 & 0 & 11 & -3 & 33 & -1 & 1 & 0 & 0 & 6 & 36 & 6 \\
\hline CHL & -1 & -1 & -5 & -4 & -7 & -1 & 2 & 21 & 5 & 252 & 2 & 13 & 0 & 0 & 28 & 303 & 24 \\
\hline NZL & 2 & 2 & 1 & 45 & 33 & 0 & 1 & 128 & 41 & 35 & 7 & 36 & 47 & 0 & 3 & 380 & 66 \\
\hline ZAF & 0 & 2 & 2 & 20 & 13 & 1 & 1 & 7 & 5 & 35 & 1 & 3 & 1 & 1 & 18 & 109 & 18 \\
\hline RofWX $^{\mathrm{a}}$ & -6 & -4 & -16 & -3 & -38 & -28 & -39 & 4 & -4 & 100 & 21 & 11 & 11 & -3 & -60 & -54 & -3 \\
\hline World & 27 & 221 & -94 & 174 & 463 & 22 & 7 & 841 & 256 & 2305 & 231 & 557 & 63 & 11 & 236 & 5321 & 19 \\
\hline$\%$ change & 4 & 15 & -3 & 4 & 8 & 2 & 1 & 20 & 16 & 309 & 18 & 38 & 13 & 11 & 13 & 19 & \\
\hline
\end{tabular}

${ }^{\text {a }}$ OWEM = other Western European wine importers (excl. France, Belgium/Luxembourg, Germany and Great Britain), OECA $=$ other Eastern Europe and former Soviet Union (excl. Russia),

OASIA $=$ other Asia (excl. China and Japan),

RofWM $=$ other wine importers not shown here, and

RofWX $=$ other wine exporters not shown here.

Source: From modelling results summarized in Anderson and Wittwer (2013) 
Figure 5: Evolution of UK trade composition in wine, 1969 and 2009

UK net trade by partner, values

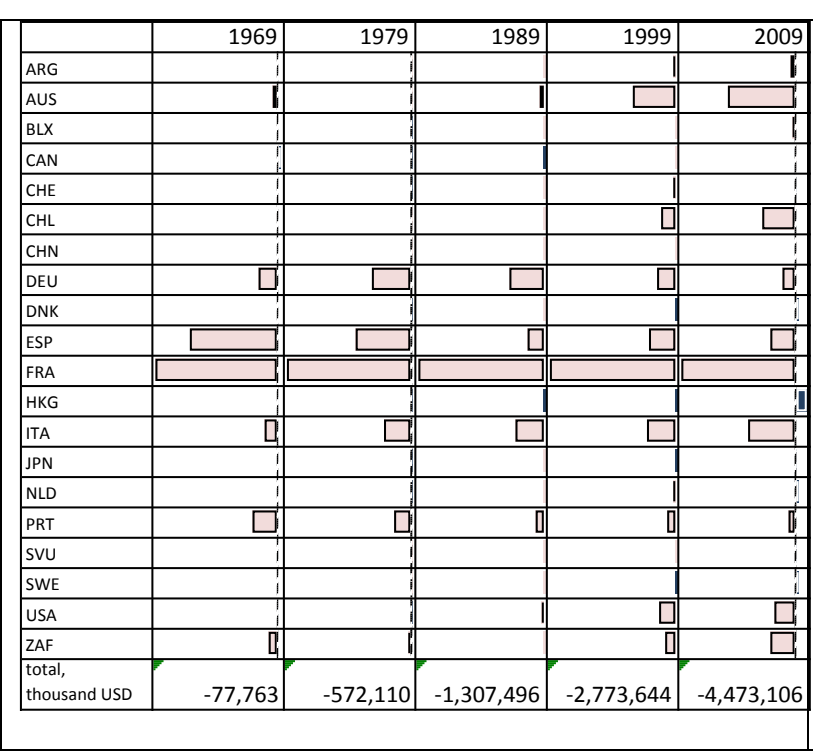

UK IIT by partner, indexes

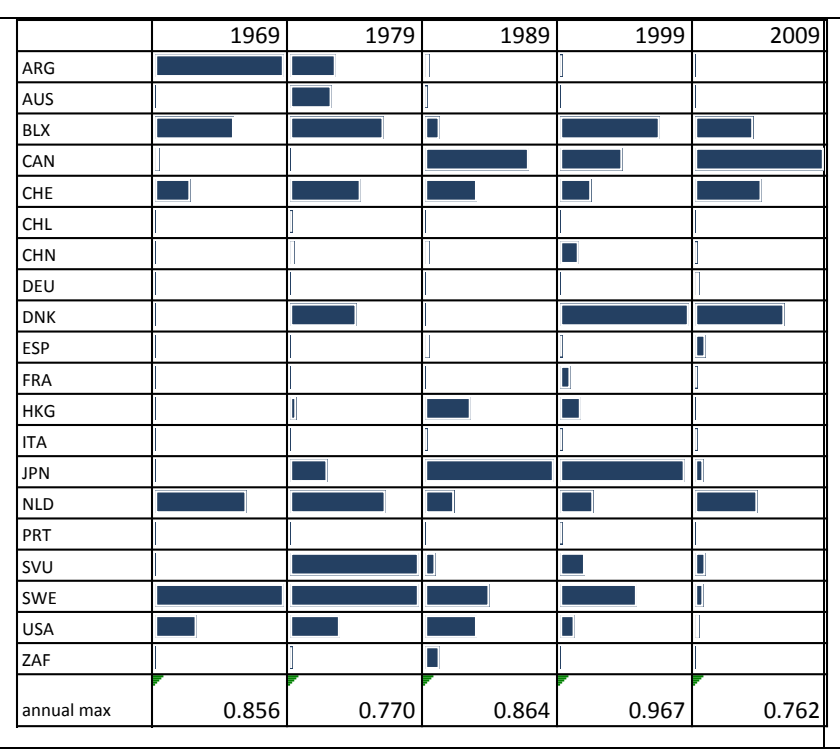

UK IIT by partner, values

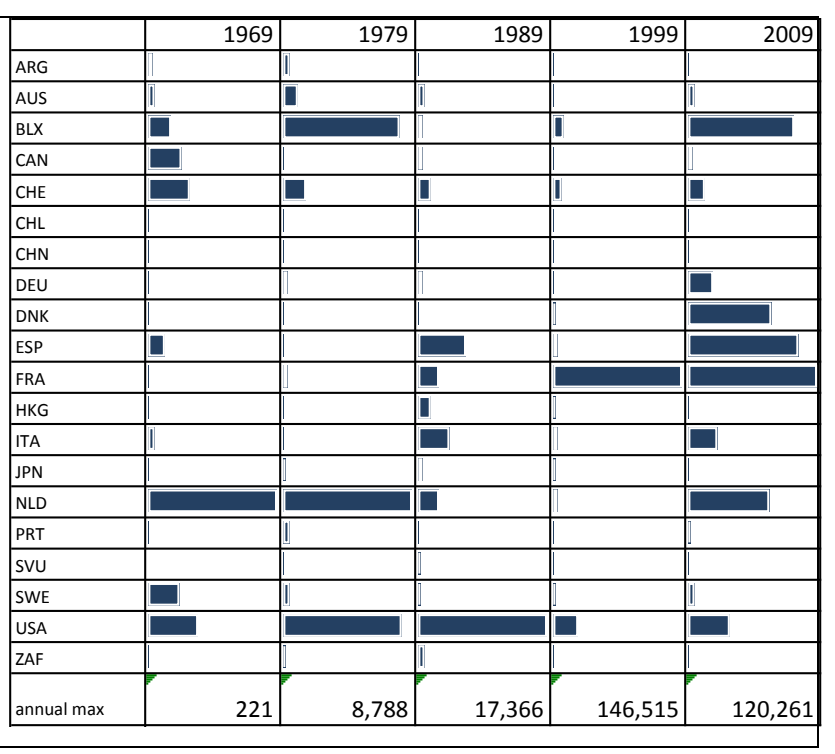

${ }^{\text {a }}$ Cells are scaled by maximum value for each year.

Source: Authors' calculations based, on UN COMTRADE data 